\title{
Implementation of voluntary verification of sustainability for solid biomass - a case study from Denmark
}

\author{
Søren Larsen ${ }^{1,2,3^{*}}$ (D), Niclas Scott Bentsen² ${ }^{2}$ and Inge Stupak ${ }^{2}$ (D)
}

\begin{abstract}
Background: Renewable energy and biomass are becoming increasingly important energy sources to help mitigate climate change and meet national renewable energy targets. This will lead to a substantial growth in solid biomass consumption for heat and electricity, but questions about its sustainability have been raised. Danish energy companies have addressed these issues with sustainability criteria in a voluntary industry agreement since 2016. The aim of this study was to synthesise and evaluate biomass sourcing in the Danish energy sector and its compliance with voluntary sustainability criteria.
\end{abstract}

Methods: We collected energy companies' public industry agreement sustainability reports and compiled the included information into a dataset that allowed us to compare and analyse the Danish energy sector's biomass sourcing, compliance and implementation of sustainability criteria in 2016 and 2017. Furthermore, we analysed the supply chains and feedstock use of Danish energy companies.

Results: In Denmark, medium to large energy companies documented that $57 \%$ and $70 \%$ of their biomass sourcing was in compliance with the sustainability criteria in 2016 and 2017, respectively. To show compliance with the sustainability criteria, sustainable forest management certification was most common in 2016 while risk-based certification prevailed in 2017. Most biomass is sourced and reported sustainability compliance by a few large companies. Wood pellets are sustainability reported and sourced in significantly larger volumes than wood chips. Danish energy companies source solid biomass from local to global scales, but especially from countries around the Baltic Sea.

Conclusions: The Danish approach to sustainable sourcing with voluntary sustainability criteria has been successfully implemented for most of the wood sourced for energy by medium to large energy companies in Denmark. The implementation of this approach shows that it has been possible within a couple of years to implement sustainability governance with risk-based criteria for multiple energy companies that source solid wood biomass at the megaton scale. A risk-based approach to implementation of sustainability criteria for forest biomass has also been chosen by the European Union (EU) and will be implemented through the EU Renewable Energy Directive from 2021.

Keywords: Solid biomass, Sustainability criteria, Bioenergy governance, Denmark, Forest certification, Case study, Renewable energy directive, Sustainable forest management, Energy policy

\footnotetext{
*Correspondence: SLA@danskenergi.dk

'Danish Energy, Vodroffsvej 59, DK-1900 Frederiksberg C, Denmark

${ }^{2}$ Department of Geosciences and Natural Resource Management, Section for

Forest, Nature and Biomass, University of Copenhagen, Rolighedsvej 23,

DK-1958 Frederiksberg C, Denmark

Full list of author information is available at the end of the article
}

(c) The Author(s). 2019 Open Access This article is distributed under the terms of the Creative Commons Attribution 4.0 International License (http://creativecommons.org/licenses/by/4.0/), which permits unrestricted use, distribution, and reproduction in any medium, provided you give appropriate credit to the original author(s) and the source, provide a link to the Creative Commons license, and indicate if changes were made. 


\section{Background}

\section{The Danish energy system}

Renewable energy is important as a means to reduce countries' dependence on fossil fuels and their related greenhouse gas (GHG) emissions. Solid biomass plays a key role in this development, and it is currently the largest source of renewable energy in the EU28 as well as in Denmark [38]. For this study, biomass is defined as solid biomass, i.e. wood in the form of wood pellets and wood chips unless otherwise mentioned. Biomass is expected to contribute substantially to the renewable energy targets of 2020 [4] and 2030, despite large uncertainties about future biomass supplies and demands. At present, most of the biomass used in the European energy systems originates from Europe, but imports from countries outside the EU are expected to increase $[13,38]$.

The gross energy consumption in Denmark was 772 PJ in 2017, showing only a slightly declining trend since 1990. In the last decades, the energy sector has experienced an increasing diversification in fuel inputs driven mainly by reduced coal consumption and increased biomass, wind and solar resources [38]. Of the gross energy consumption in 2017, approximately $30 \%$ came from renewable energy, with biomass alone, including biological waste, contributing 21.5\%, compared to $6.7 \%$ in 2000 . Solid biomass, including straw but excluding biological waste, contributed $16.4 \%$ in 2017 , thus constituting $50 \%$ of the renewable energy supply. By 2017, the total Danish energy sector consumption of solid biomass was 2.5 Mt of wood chips, 2.3 Mt of wood pellets and $0.2 \mathrm{Mt}$ of wood waste (Fig. 1a, Table 1). An increasing part of the demand is met by imported wood pellets and wood chips (Fig. 1b). A significant part of these resources are also used outside the energy sector (Table 1), in households (firewood, wood pellets) (Table 1). For the purpose of this paper, we define the "energy sector" as the heating plants and combined heat and power plants (CHPs), which are connected to district heating networks and which have public, semi-public or cooperative ownership. Outside the "energy sector" is a diverse group of primarily private dwellings and vacation homes with wood and pellet stoves, process heat for industries, public service institutions, agriculture, forestry and horticulture [38].

Various forms of public ownership is predominant in the Danish energy sector, which consists of few centralised CHP plants and a large number of decentralised $\mathrm{CHP}$ and district heating plants. The centralised $\mathrm{CHP}$ plants are mostly located close to ports to allow for fuel deliveries by ship and enable sea water cooling. The heat supply is characterised by a comparably high penetration of district heating [103], with the dominating fuels being biomass, natural gas, waste and coal [38]. District heating supplied heat to $64 \%$ of all Danish households in 2017 [42]. A thorough statistical description of the Danish energy system is available in English for 2016 [16]. Descriptions of the district heating network and regulatory framework are also available from Danish Energy Agency [15] and Danish Energy Agency et al. [17].

\section{Policy incentives and biomass use}

The use of biomass in the energy sector in Denmark has been on the political agenda since the mid 1980s [5]. Significant political agreements driving the development were the Biomass Agreement from 1993 [80], which included a mandate on straw and wood biomass use. An agreement from 2008 liberated the fuel choice on centralised CHP plants and allowed for consumption of an additional 0.7 Mt of solid biomass (both straw and
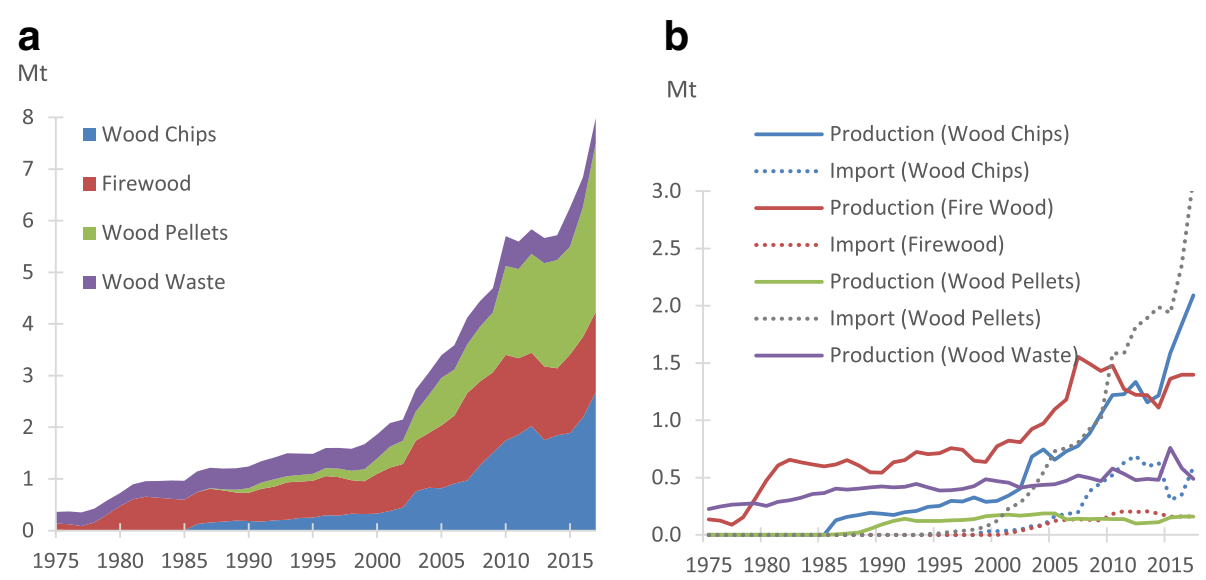

Fig. 1 Consumption of solid biomass (wood chips, wood pellets and wood waste) in the energy sector in Denmark 1975-2017 (a), and domestic production and import of solid biomass (wood chips, wood pellets, wood waste and firewood) in Denmark 1975-2017 (b). Adapted from Energistyrelsen [38] 
Table 1 Consumption of solid wood biomass in and outside the energy sector in Denmark in 2017 and the proportion of this consumption liable to the Danish "Industry Agreement to ensure sustainable biomass (wood pellets and wood chips)"(IA) [18] relative to both energy sector and total consumption, respectively. The IA is described in following paragraphs. Based on data from Energistyrelsen [38] and "Additional file 1". Wood waste is not part of the IA and firewood is not used in the energy sector [38]

\begin{tabular}{llllll}
\hline & Wood Chips & Firewood & Wood Pellets & Wood waste & Total \\
\hline Total consumption (Mt) & 2.68 & 1.56 & 3.26 & 0.49 & 7.99 \\
Energy sector consumption (Mt; \% of total) & $2.50(94 \%)$ & $0(0 \%)$ & $2.28(70 \%)$ & $0.20(40 \%)$ & $4.98(62 \%)$ \\
Consumption outside energy sector (Mt; \% of total) & $0.17(6 \%)$ & $1.56(100 \%)$ & $0.98(30 \%)$ & $0.29(60 \%)$ & $3.01(38 \%)$ \\
Percentage of energy sector consumption liable to the IA (\%) & $53 \%$ & $0 \%$ & $91 \%$ & n.a. & n.a. \\
Percentage of total consumption liable to the IA (total) & $49 \%$ & $0 \%$ & $63 \%$ & $57 \%$ \\
\hline
\end{tabular}

n.a. not available

wood) on two of the largest plants [36]. EU strategies and legislation also shaped the solid biomass use in the Danish energy sector. The 2001 Directive (2001/77/EC) [94] on promotion of electricity production on renewable resources recognised biomass as renewable, and the EU Biomass Action Plan from 2005 identified a number of initiatives to boost bioenergy [74]. In order to meet the national targets for renewable energy as set by the Renewable Energy Directive (Directive 2009/28/EC (REDI)) [46], the Danish National Renewable Energy Action Plan (NREAP) stipulated an increased consumption of wood chips of 32 PJ by 2020 relative to 2005 [65]. Finally, the national commitments under the Kyoto Protocol [67] of 1997, which entered into force in February 2005, have provided a policy incentive for countries to increase the amount renewables in the energy system. Denmark committed itself to GHG emissions reduction of $21 \%$ during the commitment period 2008-12 relative to 1990 [36].

In 2012, all political parties in the Danish parliament and the government agreed upon the energy policy for 2012-2020 [87]. As a part of this agreement, an analysis was conducted to explore the potential role of biomass in the Danish energy system. The analysis was published in 2014, and it concluded that there are current and future sustainability challenges connected to the Danish consumption of solid biomass in the heating and CHP sector [35]. At about the same time, the policy frameworks for biomass fuelled by CHPs were changed to favour increased use of biomass [64]. In 2018, the Danish government, with support from all parties in the Parliament, agreed to continue these favourable conditions until 2030 [100].

Various policy instruments are being employed to support the deployment of renewable energy. Exemptions from fuel and $\mathrm{CO}_{2}$ taxes and different forms of feed-in tariffs and feed-in premiums (FIP) on renewable electricity have been the main incentives in Denmark since 1993 [63, 71]. For biomass for electricity production, different FIPs have been in place since the early 2000s $[39,84]$. The value of this subsidy is for most plants about 2 EUR $\mathrm{kWh}^{-1}$. From April 2019 and onwards, this subsidy is available for 15 to 20 years depending on whether the CHP is converted from coal to wood pellets or if it is a new power plant. Solid biomass CHPs built after April 2019 are eligible for FIPs similar to other renewable energy projects [34, 39]. A complete overview of subsidies for renewable energy including biomass in Denmark is available from the Danish Energy Agency Energistyrelsen [39].

\section{Biomass sustainability frameworks}

As the use of biomass for energy has been growing over recent decades, sustainability concerns have been expressed by several NGOs, researchers and other stakeholders. Concerns are for example that the use of biomass does not lead to real GHG emission savings [10, 47,82 ]; that biomass is not a truly renewable energy source [40]; that ecologically sensitive areas and habitats will be harmed [19]; and that undesirable indirect landuse changes (iLUC) will take place [10]. These discussions are still ongoing and are a topic Danish Energy companies, and organizations are addressing as part of their corporate social responsibility, sustainability or strategy programmes, e.g. HOFOR [61]; Ørsted [79].

The rise of such concerns led to the introduction of sustainability criteria for bioliquids in RED I, which was adopted in 2009 [46]. It was questioned, however, if sustainability criteria for solid and gaseous biomass used for heat and electricity could lead to market distortions [74]. In 2010, the EU issued recommendations which encouraged Member States to establish national sustainability criteria for solid and gaseous biomass [43]. The recommendations build on the RED I requirements for bioliquids [74].

Belgium had already introduced criteria for GHG emission reductions in 2001, but the United Kingdom (UK) was first to introduce such national requirements in 2009, with adoption of national legislation in 2013, which took effect in October 2015 (Table 2) [73, 74]. In 2012, The Danish government suggested 
Table 2 Indicative comparison of sustainability issues for forest biomass as included in Denmark, the Netherlands, the United Kingdom, Belgium and the newly adopted EU RED II [44, 45, 66, 73]. The displayed issues are not necessarily named in the same manner in the individual frameworks

\begin{tabular}{|c|c|c|c|c|c|}
\hline Sustainability criteria & Belgium & United Kingdom & Denmark & The Netherlands & EU RED ॥ \\
\hline Legality $^{a}$ & No & Yes & Yes & Yes & Yes \\
\hline Sustainable forest management ${ }^{b}$ & No & Yes & Yes & Yes & Yes \\
\hline GHG emission savings from bioenergy value chains ${ }^{c}$ & Yes & Yes & Yes & Yes & Yes \\
\hline Carbon stocks and sequestration & No & No & No & Yes (carbon debt) & Yes (LULUCF accounting) \\
\hline Indirect effects & No & No & No & Yes (iLUC) & No \\
\hline Governmental control & Yes & Yes & No & Yes & Yes \\
\hline Start time & 2001 & 2015 & 2016 & 2016 & 2021 \\
\hline Implementation & Implemented & 2015- & 2016-2019 & 2018-2022 & $2021-$ \\
\hline
\end{tabular}

LULUCF land use and land-use change and forestry

${ }^{a}$ Covered by the EU Timber Regulation 995/2010 [95]

${ }^{\mathrm{b}}$ There are differences in the included sustainable forest management criteria, but it is outside the scope of this paper to further analyse these

'Thresholds differ among countries

that the two Danish industry associations, Danish Energy and the Danish District Heating Association, and their member companies establish an industryinitiated voluntary sustainability framework for wood chips and wood pellets. This resulted in the "Industry agreement to ensure sustainable biomass (wood pellets and wood chips)" (IA) being concluded and approved by the government in 2014 [18, 68]. The implementation of the IA started on 1 August 2016. The agreement is expected to be fully phased in by the end of 2019 (Table 2). In 2017, an agreement was also concluded in the Netherlands, with implementation taking place from 2018 to 2022 [77].

At EU level, the European Commission proposed revisions to the Renewable Energy Directive in 2016, which included the introduction of risk-based sustainability criteria for solid and gaseous biomass used for heat and electricity in the EU [44]. These sustainability criteria were developed for transport biofuels based on the RED I, but new sets of sustainability criteria were suggested for the Directive to additionally cover solid and gaseous biomass used for heat and power generation. After a legislative process in 201618, the new Renewable Energy Directive (Directive (EU) 2018/2001, RED II) was finally adopted in 2018, becoming statutory from January 2021 [45, 96]. RED II introduces risk-based sustainability criteria for solid and gaseous biomass used for heat and power in the EU. Some of the criteria are specific to solid biomass from forests, while others are specific to other types of biomass.

The sustainability criteria of solid biomass from forests differ to some extent among EU Member States (Table 2), with the main differences being the approach to effects on the carbon cycle and carbon sequestration [66, 73]. All countries and the EU RED
II establish criteria for GHG emissions savings in the bioenergy value chains, even if thresholds are not similar. The overall regulatory approaches also differ. In Belgium, the UK and the Netherlands, sustainability criteria are linked to governmental subsidies. They have been implemented through laws and compliance is subject to governmental control. In Denmark, compliance with national sustainability criteria is voluntary and not linked to subsidies. Currently, there is to our knowledge little mutual learning taking place between national systems in different countries, and publication and communication of experiences from these systems are not yet taking place in public debates.

Parallel processes have taken place in the private sector. In order to avoid trade barriers for solid biomass fuels due to existing differences in company policies and emerging differences in national systems [73], the larger European energy companies started a collaboration in 2010, to develop common sustainability criteria for solid biomass [74]. This collaboration resulted in the launch of a new certification system, Sustainable Biomass Program (SBP), in the autumn of 2015 [74]. Multiple other national-, regional-, and international initiatives exist, which have relevance to biomass sustainability, with some of the most important being certification systems for sustainable forest management (SFM) [50, 70, 81]. Two major systems exist, the Forest Stewardship Council (FSC) and the Programme for the Endorsement of Forest Certification (PEFC). The SBP system accepts FSC and PEFC certification as verification of their SFM criteria [91].

\section{Energy company policies}

Two of the largest Danish energy companies, Ørsted and HOFOR, have actively participated in the 
collaboration to develop SBP, and address biomass sustainability as part of their corporate social responsibility, or in specific sustainability strategies and programmes, see HOFOR [61]; Ørsted [79].

In 2007, the largest Danish energy company, DONG Energy (named Ørsted from 2017) had a code of conduct for responsible wood sourcing, which required that the solid biomass they consume is certified [22]. Early attempts to address sustainability also include a report on solid biomass resources, markets and sustainability commissioned by several larger Danish district heating companies in 2010. The report recommends that governance of biomass sustainability including certification should be handled by the EU or the Danish government through binding criteria. Furthermore, it suggests that energy companies should require certificates of origin for their biomass sourcing and that solid biomass should meet the criteria recommended by the EU in the same year [12, 43]. Focus on sustainability governance of solid biomass within Danish energy companies thus gradually emerges around 2007-2014. In 2013, the Danish Energy and the Danish District Heating Association, which most Danish energy producers are members of, published a booklet on sustainability of solid biomass for energy [20], and in late 2014, the IA, described below, was agreed upon.

\section{The Danish Industry Agreement}

The Danish IA has eight sustainability criteria with several quantitative and qualitative indicators under each criterion (Table 3 ). The sustainability criteria were developed with the requirements of the UK Procurement Policy as a starting point, the so-called Central Point of Expertise on Timber criteria [11]. These criteria had already formed the basis for the Danish public procurement policy for wood and wood products, before the IA [90]. Various certification systems, such as the SBP, the FSC and PEFC, are approved as eligible to verify compliance with the SFM criteria of the IA. Also, other forms of documentation are accepted, on a case by case basis involving third-party auditing. SBP certification also covers collection of all relevant data for calculations of value chain GHG emission savings, while the calculations are done by energy companies, to show that the biomass meets the thresholds set by the IA.

Compliance with the IA is documented through yearly reporting by each energy company. Reports can be developed or written by third-party auditors, and they are made public on each energy company's website and on the websites of Danish Energy and the Danish District Heating Association, depending on energy company memberships [18].

\section{Aims}

At present, there is little specific knowledge available on the documentation of sustainable wood sourcing of energy companies operating under national level sustainability frameworks in European Union Member States. There are a few exceptions such as the reporting by the British energy company DRAX [24]. In Denmark, the IA requires that energy companies publish annual reports with information on how they document the sustainability of the biomass, according to the sustainability criteria of the IA. However, the information from these reports has not yet been presented in a synthesized form. As experiences gained in such processes should form a basis for continued learning and improvements, this study aims to synthesise the information about Danish energy companies' reporting, as a basis for analysing their solid biomass sourcing, and evaluate the degree to which it is in compliance with the requirements of the IA. The study analyses the development during the first 2 years of the IA implementation, 20162017. We believe that the results will benefit the further implementation of the IA and solid biomass sustainability governance in general.

\section{Methods}

\section{Sustainability reports}

Our analysis was based on all IA reporting by Danish energy companies in 2016 and 2017. These reports are published by energy companies as part of their obligations in relation to the IA (Table 3 ). The reports of 2016 are published in 2017 and reports of 2017 are published in 2018 (Table 4).

\section{Template for data compilation}

We have designed a template for synthesis of the information from the submitted reports of the 17 energy companies (Table 5). The compiled information includes 16 variables. During data compilation, we have translated data from the reports into English. All data from the reports is included in the Additional file 1 as an MS Excel Spreadsheet.

The reports do not always present data in a consistent form, e.g. some companies report biomass sourcing as a percentage of total sourcing and other report everything in volumes. This has led to small rounding errors in the dataset. Similarly, missing data in the Additional file 1 indicates that data was not published or available from the reports.

\section{Supply chains}

The sustainability report's information about country of origin was used to classify supply chains into different, but somewhat, overlapping categories: global, European, regional and local. We use the term "supply chain levels" 
Table 3 Overview of sustainability criteria and other requirements in the Danish Industry agreement to ensure sustainable biomass (wood pellets and wood chips) (IA). The content of this table is condensed and adapted from the agreement published by Danish Energy and Danish District Heating Association [18]

Criteria
1. Legality
2. Protection of forest's ecosystems
3. Forest productivity and carbon cycle
4. Healthy and well-functioning forests
5. Protection of biodiversity, sensitive
areas and areas worthy of preservation

6. Social and work-related rights

7. CO2 emission limits for biomass value chains

8. Additional requirements: carbon cycle, forest carbon stock, indirect land-use change and indirect wood-use change

Other requirements

Compliance and publication

Documentation

Timeframe

Plants included

Types of biomass
Indicator

- Logging only from legally designated areas

- Payment of relevant taxes and duties

- Logging in compliance with forest and environmental legislation

- Indigenous people's rights must be respected

- Compliance with customs and trade legislation

- Forest management must ensure the preservation of the forest ecosystem - Assessment of the environmental impact related to logging

- Impact assessment of forest management on ecosystems and biodiversity

- Scheme to minimise negative impact on ecosystems and biodiversity

- Management of forest ecosystems must ensure the least negative impact on forest productivity and carbon sequestration

- Forest management must ensure healthy and well-functioning forests

- Forest management must ensure protection of biodiversity, sensitive areas and areas worthy of preservation

- Identification of particularly vulnerable areas

- Protection of designated areas, e.g. soil erosion, high biodiversity, water resources

- Forest management must protect social and work-related rights

- Identification, documentation respect of original inhabitants' rights

- Establishing complaint mechanisms

- Employees have the right to organise

- Child labour, forced labour and discrimination is not allowed

- Only biomass with specific value chain emissions is allowed

- Biograce II is chosen as calculation method

- The industry aims to not use biomass that leads to deforestation, iLUC, iWUC nor that negatively impacts quality and quantity of forest resources in the medium and long term

- This criterion is not yet implemented and is not yet documented. If standardised methods are developed, the industry must accept these methods before incorporation into IA

- Compliance with IA is documented by yearly third-party audited, public reports that are published on company websites

- There are no legal consequences for non-compliance

- Compliance with criteria 1-6 can be documented through the certification system developed by Sustainable Biomass Partnership (SBP)

- Certification by Forest Stewardship Council (FSC) and Programme for the Endorsement of Forest Certification (PEFC) is also recognised

- Other appropriate forms other than certification are also recognised ("Alternative documentation") — must be third-party audited

- Energy companies shall document on an annual basis the following proportion (by weight) of wood pellets and wood chips are in compliance with the IA: 2016 (from August 1st): 40 \%, 2017: 60 \%, 2018: 75 \%, 2019: Fully phased in, but $10 \%$ can be in compliance with only criterion 1 (legality).

- All CHP and heating plants in Denmark generating heat and/or power from wood chips and wood pellets are covered by the IA

- Only plants > $20 \mathrm{MW}$ th are subject to documentation requirements

- IA applies only to wood pellets and wood chips from forest areas to refer to these different geographical scales. Global level is sourcing from outside Europe, while European level covers countries in continental Europe. Regional level covers countries around the Baltic Sea, and local is the area around the CHP or heating plant, typically within a radius of about $50-100 \mathrm{~km}$ from the plant.

\section{Unit conversions}

In some instances, we have converted between energy and mass units for biomass. This was done based on conversion values used by official Danish Statistics for energy content (wood chips: 9.3 GJ metric tonne ${ }^{-1}$, wood pellets: 17.5 GJ metric tonne ${ }^{-1}$, wood waste: 14.7 
Table 4 Company names, websites and references to annual reports for energy companies submitting sustainability reports to demonstrate compliance with the IA. Presence or absence of an " $x$ " indicates whether a company published a report for that year's solid biomass sourcing

\begin{tabular}{llllll}
\hline Company name & $\begin{array}{l}\text { Report } \\
2016\end{array}$ & $\begin{array}{l}\text { Report } \\
2017\end{array}$ & Company website & Reference & $\begin{array}{c}\text { Reference } \\
\text { 2016 report }\end{array}$ \\
2017 report
\end{tabular}

GJ metric tonne ${ }^{-1}$ and firewood: $16.1 \mathrm{GJ}$ metric tonnes ${ }^{-1}$ [28-31].

\section{Results}

\section{Total biomass sourcing}

The total sourcing of forest biomass in the Danish energy sector (plants $>20 \mathrm{MWth}$ ), as reported to the IA, was about 1.2 Mt in 2016 (August-December) and 3.4 Mt in 2017 (January-December) (Fig. 2). Most of the biomass consumption is concentrated in only a few energy companies. Ørsted, VEKS and HOFOR were the largest consumers in both 2016 and 2017 with $78 \%$ and $79 \%$ of total sourcing, respectively. Ørsted alone accounted for 2.1 Mt of the total 3.4 Mt sourced in 2017.

\section{Biomass sourcing at different supply chain levels}

Most companies did not report sourcing details such as country of origin and species quantitatively. However, the information available suggested that Danish energy companies source biomass from all supply chain levels, including global, European, regional and local. Large CHPs with seaports can source wood chips and wood pellets transported to the plant on freight ships. These energy companies include Ørsted, HOFOR, Verdo and BEOF. They sourced most of their imported biomass from countries around the Baltic Sea, including Latvia, Estonia, Lithuania, Russia, Poland, Norway and Sweden (the regional supply chain level), some in Portugal, France, Germany (European supply chain level), and some from further away, e.g. the U.S.A., Swaziland, Australia (the global supply chain level), see also Additional file 1.

Smaller CHPs and heating plants without seaports used biomass, mostly wood chips, transported to the site on trucks (local supply chain level), or in some cases, biomass unloaded at a seaport and shipped by road to the CHP or heating plants. Examples include Halsnæs Varme, Skanderborg-Hørning, Sønderborg Fjernvarme, and Hjørring Varmeforsyning (see Additional file 1). When reporting on compliance with the EU Timber Regulation (EUTR), most companies reported that either they source no biomass outside EU or they did not disclose the EUTR status of biomass sourcing. Only few companies published details about their EUTR compliance.

\section{Feedstock types}

Wood pellets accounted for $65 \%$ and $61 \%$ of the wood sourcing in 2016 and 2017, respectively, and wood chips correspondingly for $35 \%$ and $39 \%$. Some wood was delivered at the plant as whole logs and chipped on site (Additional file 1). The use of wood from outside forests was reported by about 10 companies each year, but 
Table 5 Information categories, variables and their units or the value they can take

\begin{tabular}{|c|c|c|}
\hline Information category & Variable & Unit/values \\
\hline \multirow[t]{5}{*}{ Feedstock amounts } & Wood chips & \multirow{2}{*}{$\begin{array}{l}\text { Mg (adding up to "Total from forests") } \\
\% \text { (adding up to 100\%) }\end{array}$} \\
\hline & Wood pellets & \\
\hline & Total from forests & $\mathrm{Mg}$ \\
\hline & From outside forests & $\mathrm{Mg}$ \\
\hline & Total from forest and outside forest & $\mathrm{Mg}$ \\
\hline \multirow[t]{3}{*}{ IA-SFM compliance for forest biomass } & SFM certification & \multirow[t]{3}{*}{$\%$, adding up to $100 \%$} \\
\hline & Alternative SFM documentation & \\
\hline & Undocumented & \\
\hline \multirow[t]{4}{*}{ Verification systems } & FSC & \multirow{4}{*}{$\begin{array}{l}\% \text {, not necessarily adding up to } 100 \% \\
\text { One shipment of biomass can be certified through } \\
\text { more than one certification body and thus count } \\
\text { towards two or more verification systems } \\
\text { Some energy companies do not report certification body }\end{array}$} \\
\hline & PEFC & \\
\hline & SBP & \\
\hline & Alternative documentation & \\
\hline \multirow[t]{3}{*}{ Other information } & Country of origin & List of countries, sometimes with percentage distribution \\
\hline & Species & $\begin{array}{l}\text { Species names or categories, or "Non-disclosed", which can } \\
\text { both mean that the company does not publish tree species } \\
\text { composition or that the company was not informed by their suppliers }\end{array}$ \\
\hline & EUTR DDS & $\begin{array}{l}\text { "No non-EU biomass", "Non-disclosed", "SFM Compliant } \\
\text { biomass: No non-EU biomass". "insignificant risk of illegality } \\
\text { for non-EU biomass" }\end{array}$ \\
\hline Auditing and reporting service & Company & $\begin{array}{l}\text { Name of the auditing company and reporting service } \\
\text { company (in all cases NepCon) }\end{array}$ \\
\hline
\end{tabular}

compared to the total sourcing it was a very small fraction (approximately $0.03 \mathrm{Mt}$ in 2016 and approximately $0.04 \mathrm{Mt}$ in 2017). However, for some small companies, it can constitute a substantial part of their total wood sourcing (approximately $20 \%$ ). Because solid biomass from outside forests is not covered by the IA, there is little information about it in the sustainability reports.
However, some companies mention in the reports that it is for instance SRC willow [3], horticultural wood waste $[89,93]$, hedgerows and fruit tree plantations [99].

Some companies provided tree species information for their feedstock, often in very general terms such as "mixed conifer and mixed broadleaves". Only the two companies with the largest sourcing, Ørsted and HOFOR, provide

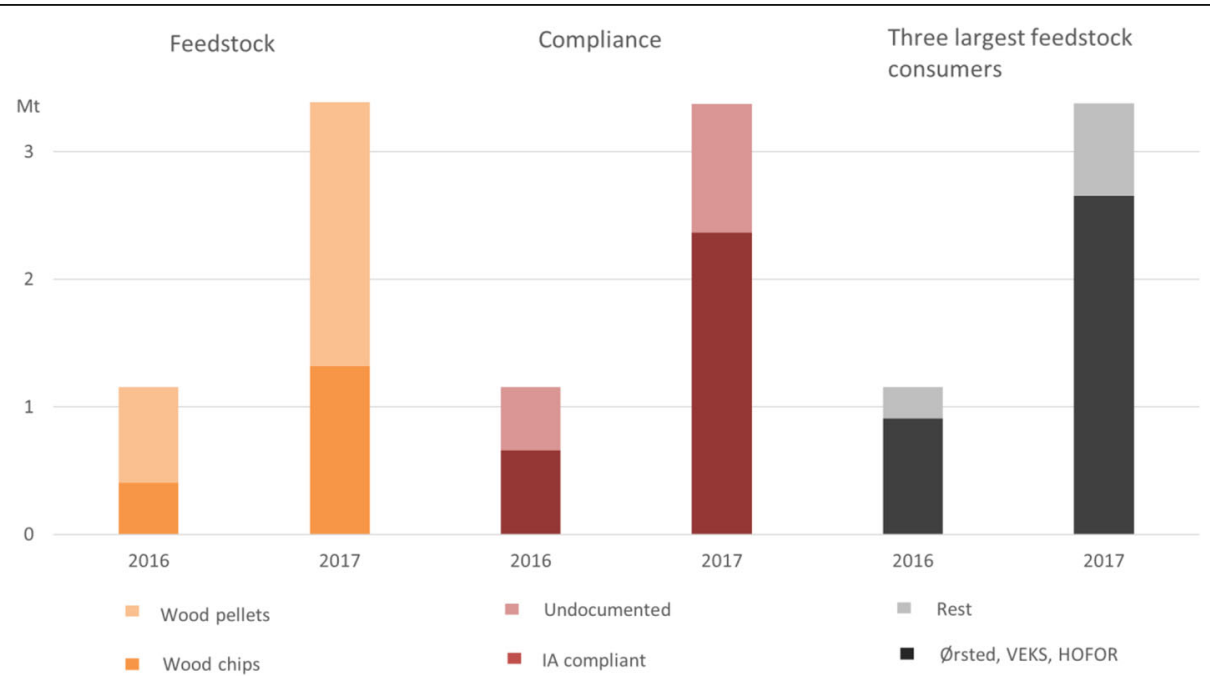

Fig. 2 Total biomass sourcing liable to the IA in 2016 and 2017, distributed to feedstock type, IA compliant and undocumented biomass, and the three largest (by volume of biomass) energy companies versus others. Data from "Additional file 1" 
more precise information for their global and European level certified supply chains. For 2016 and 2017, Ørsted reported that biomass from the southeastern USA was made from mixed hardwoods and three different pine species (in 2017, 19\% broadleaves and $81 \%$ conifers), while biomass from Australia was mixed conifers. Biomass from Portugal was from eucalypt and maritime pine (Pinus pinaster), and biomass from France was mixed broadleaves. HOFOR reported that their IA-SFM compliant biomass included alder (Alnus spp.), birch (Betula spp), Norway spruce (Picea Abies), Scots pine (Pinus sylvestris), and poplar (Populus spp). Non-IA-SFM compliant biomass from the Baltic states additionally included larch (Larix spp), while species information was not available for biomass from the U.S.A.

\section{Industry Agreement and compliance}

In $2016,57 \%$ of the reported wood volume was documented to be compliant with IA requirements, and in 2017, this was $70 \%$ (Fig. 2). The IA requirements for the phase-in period were a minimum of $40 \%$ compliant biomass in 2016 and $60 \%$ in 2017, indicating that the implementation has been successful so far.
Compliance was ensured by SFM certification (FSC or PEFC) for $75 \%$ and $44 \%$ of the IA compliant biomass in 2016 and 2017, respectively. The corresponding riskbased SBP certified biomass covered $13 \%$ and $54 \%$, respectively (Fig. 3). Various types of alternative documentation were also used, but this fraction was reduced from 2016 to 2017 (Fig. 3).

\section{Industry Agreement non-compliance}

In 2016 and 2017, three energy companies did not reach the targeted share of IA compliant biomass, and by April 2019, two other companies have not published a sustainability report for one of those 2 years. Additionally, six energy companies were supposed to report according to the IA because they are larger than $20 \mathrm{MWth}$, but they have not published reports for either 2016 or 2017. These six companies each used less than 0. $5 \mathrm{Mt}$ of wood chips and/or wood pellets in 2016, which amounts to a total of approximately $0.15 \mathrm{Mt}$ for all of them together [37], see also Additional file 1. Thus, there is no third-party audited documentation of sustainability for this

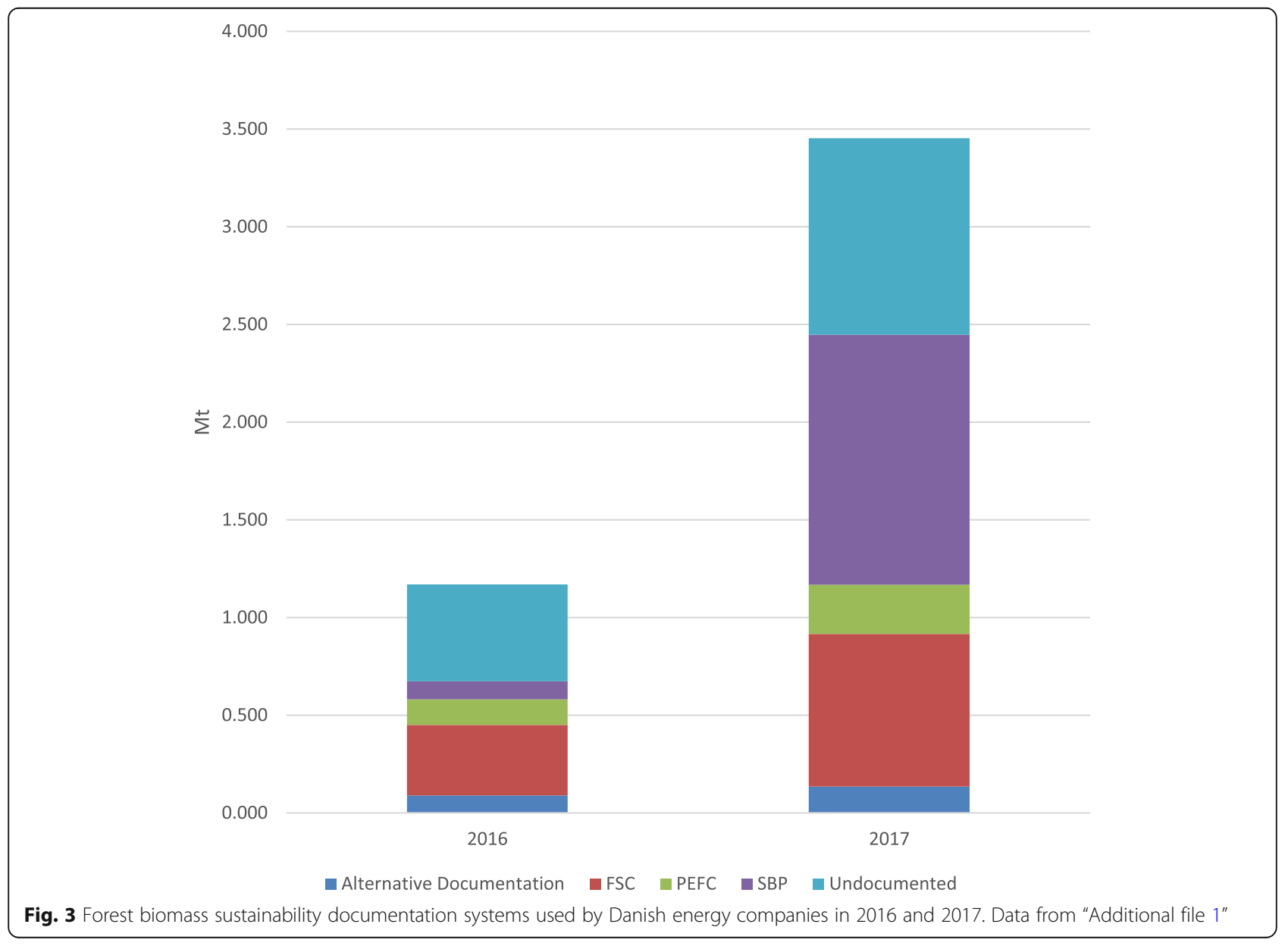


biomass and no publicly available details on feedstock types, supply chain levels, etc.

\section{Discussion}

\section{Coverage of the IA and its limitations}

This study aimed at evaluating the extent of which the current sustainability documentation for forest solid biomass consumed by the Danish CHP and heating sector is in compliance with the requirements of the IA. We found that there is generally a high degree of compliance. However, in order to achieve a thorough assessment of the effect of the IA in Denmark, it is important to consider all solid biomass consumption, also beyond what is liable to the IA. Barriers to getting a more complete picture include the following:

- There is a gradual implementation of the IA (Table 3), and it is not yet (2017) fully phased in.

- The information available from the third-party audited reports submitted under the IA is still incomplete. Three companies did not report to the IA in either 2016 or 2017, and six companies did not report to the IA for any of those 2 years.

- There is no or only little information about the noncompliant wood in the reports, which will perhaps persist for the $10 \%$ that can be used with no documentation, also after the IA is fully implemented.

- Solid biomass consumption by energy companies $<20$ MWth is not subject to documentation requirements. In 2016, there were 183 such energy companies using wood pellets and/or wood chips in Denmark [37].

- Household consumption is not subject to documentation requirements. Some information on the used amounts is available from two recent Danish surveys, but no information exists on sustainability characteristics of this wood. Also, the surveys focus on fire wood and wood pellets, with no detailed information on the use of wood chips or wood waste by households [26, 27]. In $2017,57 \%$ or of the total Danish consumption of wood for energy was covered by the IA, while almost $1.2 \mathrm{Mt}$ wood chips and wood pellets (Table 1) was used outside the energy sector to heat private homes, in industries etc.

- The IA exclusively regulates solid biomass from forest areas as defined by FAO [18]. There is no sustainability requirement in place for wood from outside forests such as hedgerows, landscaping trees, horticultural wood waste or short rotation coppice crops from agriculture. Probably, this source of biomass presently accounts for a small fraction of the total sourcing, but only very little data is available to evaluate if this is true. A recent national analysis of solid biomass resources shows that a large additional amount of domestic wood from outside forests can potentially be available for the energy sector [69].

- Tertiary biomass, i.e., post-consumer wood, is not subject to the requirements of the IA.

We suggest that a study to assess the total amount of solid biomass used for energy in Denmark, as well as the associated sustainability risk, would be useful as an element in the further clarification of the adequacy of the IA for Denmark.

\section{Two biomass markets}

Although wood consumption outside the medium to large-scale energy sector is not liable to the IA documentation requirements, this does not necessarily mean that the used wood does not meet the sustainability criteria of the IA or is covered by some other type of sustainability governance scheme. The smallscale energy sector ( $<20 \mathrm{MWth})$ is liable to the IA, but not the documentation requirements (Table 3 ). All solid biomass placed on the market in EU Member States is covered by the EUTR [95], which aims at documenting low risk of illegality. Also, some solid biomass might come from forests certified under FSC or PEFC, as is the case with all fire wood and other wood fuels from Danish state forests [76]. The two most recent Danish surveys of household wood pellet and fire wood consumption show, however, that there are no detailed statistics or information on the origins or sustainability properties for the large fraction of solid biomass for energy used outside the medium to large-scale energy sector [26, 27].

There is a risk that this situation will result in two types of markets for solid biomass for bioenergy. The first would be a market with sustainability governance and documentation requirements through the IA, which supplies the medium to large-scale energy companies, mostly with wood pellets and wood chips. This market is ramping from $40 \%$ IA coverage in 2016 to $90 \%$ in 2019 . This market will also be regulated by RED II by 2021 [45]. The second market will be supplying private homes, industry and small-scale energy plants mostly with wood pellets and fire wood. Parts of this market will have sustainability governance possibly with third-party auditing, but it is presently unknown what fraction is covered and by which systems, nor to what extent it will be covered by sustainability governance in the future. A worst-case scenario would be if this market is or develops to be an outlet for "unsustainable" biomass. 


\section{Enough information to see biomass sourcing patterns?} The results showed that three or four supply chain levels could be distinguished for solid biomass used in the Danish energy industry. These results are substantiated by a survey conducted by EA Energianalyse [27] that found $94 \%$ of the wood pellets consumed in Denmark in 2016 were imported, with most of the wood pellets originating from countries around the Baltic Sea and about 10-15\% from global supply chains. Some biomass is not included in the reporting to the IA, but about $63 \%$ of the total amount of the consumed wood pellets in Denmark in were covered 2017 [38], which is probably adequate to show the pattern.

Danish forestry organizations found in 2013 that about $55 \%$ of the Danish wood chip production was consumed by small CHPs and heating plants. Large CHPs were responsible for approximately 30\%, and approximately 24 $\%$ in 2016, of all wood chips consumed in Denmark. The remaining was consumed at small CHPs and heating plants [21, 38]. In accordance to our results, this shows that it is the small energy companies that source most of the local biomass as wood chips. This confirms that local supply chains are the most important for wood chips presently. This might change when a new large CHP in Copenhagen will start operating in 2019 with a total expected consumption of up to $1.2 \mathrm{Mt}$ wood chips per year [62]. The sourcing patterns are thus dynamic, and it is important to follow the development, to see if new concerns arise.

As discussed above, there is only scattered information and statistics available on Danish wood consumption and the energy sector does not provide much more quantitative detail in their IA reports because most energy companies provide little detail about their wood sourcing in relation to country of origin (Additional file 1). Thus, it can be difficult to analyse and evaluate the supply chains of Danish energy companies with only official statistics and IA reports. Sourcing volumes of official statistics cannot be coupled to specific energy companies and IA reports are often not sufficiently detailed.

\section{Adequacy of sustainability frameworks}

From 2021 onwards, the RED II will come into effect and overrule subsidies and inclusion of bioenergy in renewable energy targets for biomass not meeting and documenting compliance with the risk-based sustainability criteria of RED II [96].

An important discourse is whether regulatory sustainability criteria such as those in Denmark, the UK, the Netherlands, Belgium and the entire EU from 2021 are sufficiently addressing sustainability concerns, especially in terms of climate change mitigation and carbon stocks. One focal point of these criteria is ensuring sustainable forest management (Table 2). In recent years, there has been scientific disagreements as well as public debates about whether the use of solid biomass for energy is sustainable and what the climate impact of burning wood for energy is $[10,14$, 82]. Even if sustainability criteria are applied for solid biomass used for energy in the EU, there still is an argument from some scientists that it is not sufficient to ensure that there are benefits for climate, while others are concerned with biodiversity preservation. Other researchers come to different conclusions about the climate impacts of solid biomass, e.g. $([6,83]$.

Another issue relates to the complexity of wood markets and wood end-uses as well as their related sustainability governance. It is difficult to make an allencompassing sustainability scheme that can regulate every use-case and sector, and this might result in wood markets affected differently by sustainability regulation depending on end-use [73].

\section{Adequacy of certification schemes}

The biomass certification sector is very dynamic and is likely to see new developments in the near future. Some pellet and energy companies are working to increase transparency of their feedstock sourcing, with online tools to display origin, type and other information, e.g. ENVIVA, [41] and DRAX [25]. Such work is also ongoing in relation to the EUTR [97], as well as work to explore verification of sustainability indicators with spatial data [72]. This might be crucial to verify sustainability for uncertified areas, e.g. as a basis for risk assessments, as required by SBP and RED II. For implementation of RED II criteria, it also seems likely that some adjustments will take place at all regulatory levels, including legislation, in national sustainability systems and within private certification. In sourcing countries with no ratification of the Paris Agreement, new accounting systems might be needed at finer scales to demonstrate that forest carbon stocks are not declining in the long-term in biomass sourcing areas [96].

The FSC, PEFC and SBP systems are accepted by the parties to the IA for showing compliance with the SFM requirements [18]. The FSC and PEFC systems are logical choices as their criteria for SFM represent a relatively long-lasting and high degree of consensus within international and national stakeholder communities. SBP builds on the criteria of these systems, but has made an effort to develop a novel risk-based approach for uncertified forests, where the auditing focuses on criteria assessed with specified risk [91]. Criteria assessed with low risk are typically covered by well-enforced legislation; otherwise, available statistics and data may suggest that risk is low. 
Forest biomass has increasingly been used for energy since the 1980s (Fig. 1), and the associated forest practices have not been subject to any major pushbacks from societal actors. Some NGOs in Denmark consider that FSC is the only credible forest certification system [75], but governmental procurement policies have also considered FSC and PEFC as equally credible. Of the Danish forest area, around $20 \%$ is certified according to FSC and $40 \%$ to PEFC, with the major share being state forest. The risk-based approach by SBP and RED II has not yet been subject to any major criticism in Denmark, even if there has been some pushback in some other EU member states and internationally. Possible reasons can be perceptions of progress compared to existing approaches, and a relatively long tradition for communication between industry, public authorities, government and societal actors, with focus on collaboration, finding solutions and common ground. However, additional studies are possibly needed to confirm this.

\section{Future developments and perspectives}

The Danish Council on Climate Change [66] has recently suggested improvements to sustainability assurance frameworks for solid biomass. They suggest that the government establish a task force "for development of accurate and verifiable indicators that can be integrated into the existing sustainability criteria for solid biomass" with a focus on carbon stocks and the carbon cycle as well as LULUCF-regulation and indirect land-use change [66]. This shows that there are calls for strengthened sustainability governance in Denmark-also in addition to what will be required by RED II (Table 2). Some of these topics are already mentioned in the IA under criterion 8 (Table 3), but they are presently only included as encouragement not to use some kinds of solid biomass. Additionally, criterion 8 states: "If standardised methods for documenting retention of forest carbon stock, IWUC- and ILUC effects, are developed, the industry must accept these methods before they can be incorporated into the industry agreement as documentation requirements." [18]. Thus, a strengthened IA and/or sustainability criteria are already on the agenda in the energy industry as well as at The Danish Council for Climate Change which advises the government. At the time being, there are, however, no specific plans to make changes to the IA, until the implementation of RED II has taken place in 2021. The implementation of RED II into Danish law is not yet subject of any public discussions, and it is presently difficult to predict how it will be performed. It is evident that some of the requirements of RED II are different from the IA (Table 2), but RED II still allows member states to make their own sustainability criteria [96]. It is still uncertain to which extent it is needed to adapt to RED II and to which extent the current approach will be continued, but it seems likely that actors will want to build on what has been achieved up till now

\section{Conclusion}

The Danish voluntary IA has proved effective in governing the medium to large energy company sourcing of solid biomass for energy. In only 2 years, the volume of biomass that is documented to be sustainable according to the IA has gone from zero to approximately $2.5 \mathrm{Mt}$ of biomass out of a total of around $3.4 \mathrm{Mt}$. This is $71 \%$ of the total sourcing of medium to large energy companies participating in the IA and $57 \%$ of total Danish solid for energy consumption in 2017. As such, the IA has proved to be successful in including a high fraction of the Danish solid biomass in its sustainability framework from its conclusion in late 2014 to the reported status in 2017.

However, there are also challenges with this type of governance. The IA is phased in gradually from 2016 to 2019, and several energy companies are not complying with the volume requirements or have not published sustainability reports. This leads to uncertainty about the sustainability governance of these non-compliant companies and the fraction not covered by the IA because there is no third-party audited documentation for this fraction of the solid biomass sourcing. Similarly, the small-scale energy companies have no documentation requirements and the entire solid biomass use taking place outside the energy sector is also with unknown sustainability governance. Thus, there is a risk of consuming biomass without sufficient sustainability governance. No documentation exists to evaluate whether or not this is the case.

The supply chain level results show that Danish medium to large energy companies source solid biomass from supply chains at all levels, but most frequently from local or regional supply chains. There is a lack of quantitative information of sourcing regions in the IA reports. Wood pellets constitute 61$65 \%$ of the sourcing in 2016 and 2017, respectively, and the large companies source the largest volume of solid biomass. Different certification schemes are used to document compliance with the sustainability criteria. From 2016 to 2017, a shift has taken place from predominantly SFM certification in 2016 to risk-based certification in 2017.

In 2018, the European Union has adopted a new renewable energy directive that introduces sustainability criteria for solid biomass from 2021. The EU criteria are similar to the Danish criteria, but renewable energy subsidies and inclusion in renewable 
energy targets are dependent on compliance instead of the voluntary approach presently used. This Danish case study suggests that sustainability criteria for solid biomass for bioenergy are operational for medium to large energy companies and thus demonstrates that risk-based certification is an operational approach for ensuring compliance with sustainability criteria for forest-based solid biomass.

\section{Additional file}

Additional file 1: Supplemental information. (XLSX 26 kb)

\begin{abstract}
Abbreviations
CHP: Combined Heat and Power; EU: European Union; EUTR DDS: Due Diligence System according to the EU Timber Regulation; FSC: Forest Stewardship Council; GHG: Greenhouse Gas; IA: Industry agreement to ensure sustainable biomass (wood pellets and wood chips); iLUC: Indirect land-use change; iWUC: Indirect wood-use change; LULUCF: Land use and land-use change and forestry; NGO: Non-governmental organization; PEFC: Programme for the Endorsement of Forest Certification; REDI: The first renewable energy directive from 2009 (Directive 2009/28/EC); REDII: The revised renewable energy directive from 2018 (Directive (EU) 2018/2001); SBP: Sustainable Biomass Program; SFM: Sustainable forest management
\end{abstract}

\section{Acknowledgements}

The authors acknowledge Kristian Mehl and Sofie Høyer for the help with the data assimilation and Mourad Boucenna for the help with the language editing and proofreading. All three are from Danish Energy.

The authors appreciate the valuable inputs and suggestions received from the two anonymous reviewers.

\section{Authors' contributions}

SL conceived the idea, performed the data analysis and drafted the first versions of the manuscript. All authors interpreted the data, revised the manuscript and approved the final version.

\section{Funding}

SL is funded by a grant (no. 5190-00014B) from Innovation Fund Denmark. Additional funding is received from Ørsted and Danish Energy. The association Danish Energy is funded primarily through member contributions from energy companies. Many of those are part of the Industry Agreement. NB is funded by a grant (no. 5190-00014B) from Innovation Fund Denmark.

\section{Availability of data and materials}

Supplementary Information is accompanying the article.

\section{Ethics approval and consent to participate}

Not applicable

\section{Consent for publication}

Not applicable

\section{Competing interests}

$\mathrm{SL}$ is employed by Danish Energy. The other authors declare that they have no competing interests.

\section{Author details}

${ }^{1}$ Danish Energy, Vodroffsvej 59, DK-1900 Frederiksberg C, Denmark.

2Department of Geosciences and Natural Resource Management, Section for Forest, Nature and Biomass, University of Copenhagen, Rolighedsvej 23, DK-1958 Frederiksberg C, Denmark. ${ }^{3}$ Ørsted A/S, Nesa Allé 1, DK-2820 Gentofte, Denmark.
Received: 8 January 2019 Accepted: 12 June 2019

Published online: 02 August 2019

\section{References}

1. Aabenraa-Rødekro Fjernvarme A.m.b.a (2017) Statusrapport for Bæredygtig Biomasse for Aabenraa-Rødekro Fjernvarme A.m.b.a [Status Report for Sustainable Biomass for Aabenraa-Rødekro Fjernvarme A.m.b.a].

2. Assens Fjernvarme A.m.b.a. (2017) Statusrapport for Bæredygtig Biomasse for Assens Fjernvarme A.m.b.a. [Status Report for Sustainable Biomass for Assens District Heating A.m.b.a.].

3. Assens Fjernvarme A.m.b.a. (2018) Statusrapport for Bæredygtig Biomasse for Assens Fjernvarme A.m.b.a [Status Report for Sustainable Biomass for Assens District Heating A.m.b.a].

4. Bentsen N, Felby C (2012) Biomass for energy in the European Union - a review of bioenergy resource assessments. Biotechnology for Biofuels 5:25

5. Bentsen NS, Nilsson D, Larsen S (2018) Agricultural residues for energy - a case study on the influence of resource availability, economy and policy on the use of straw for energy in Denmark and Sweden. Biomass and Bioenergy 108:278-288. https://doi.org/10.1016/ j.biombioe.2017.11.015

6. Berndes $\mathrm{G}$ et al (2016) Forest biomass, carbon neutrality and climate change mitigation. European Fores Institute

7. Biomassefyret Kraftvarmeværk A/S (2018) Statusrapport for Bæredygtig Biomasse for Biomassefyret Kraftvarmeværk A/S [Status Report for Sustainable Biomass for Biomassefyret Kraftvarme A/S]\}.

8. Bornholm Energi og Forsyning (2017) Statusrapport for Bæredygtig Biomasse for Bornholms Energi og Forsyning [Status Report for Sustainable Biomass for Bornholm Energy and Utility A/S].

9. Bornholms Energi og Forsyning (2018) Statusrapport for Bæredygtig Biomasse for Bornholms Energi og Forsyning A/S [Status Report for Sustainable Biomass for Bornholms Energy and Utility A/S]

10. Brack D (2017) Woody biomass for power and heat impacts on the global climate The Royal Institute of International Affairs, London, UK

11. Central Point of Expertise on Timber (2013) UK Government Timber procurement policy - definition of legal and sustainable for timber procurement, Fifth edn. Department for Environment, Food and Rural Affairs

12. CTR, Københavns Energi, Fjernvarme Fyn, AffaldVarme Århus (2010) Biomasse på kraftvarmeværkerne - ressourcer, marked og bæredygtighed [in Danish].

13. Dafnomilis I, Hoefnagels R, Pratama YW, Schott DL, Lodewijks G, Junginger M (2017) Review of solid and liquid biofuel demand and supply in Northwest Europe towards 2030 - a comparison of national and regional projections. Renewable and Sustainable Energy Reviews 78:31-45. https:// doi.org/10.1016/j.rser.2017.04.108

14. Dale VH et al (2017) Status and prospects for renewable energy using wood pellets from the southeastern United States. GCB Bioenergy 9:1296-1305. https://doi.org/10.1111/gcbb.12445

15. Danish Energy Agency (2015) Regulation and planning of district heating in Denmark. Danish Energy Agency, Copenhagen

16. Danish Energy Agency (2018) Energy Statistics 2016. Danish Energy Agency, Copenhagen $\mathrm{K}$

17. Danish Energy Agency, Danish Board of District Heating, State of Green (2014) District Heating - Danish experiences, Copenhagen

18. Danish Energy and Danish District Heating Association (2016) Industry agreement to ensure sustainable biomass (wood pellets and wood chips) ${ }^{1}$. Danish Eenergy and Danish District Heating Association

19. Danmarks Naturfredningsforening (2018) Hvad er biomasse? Og hvorfor løser det ikke vores klimaproblemer? [What is biomass? And why does it not solve our climate problems?]. http://www.dn.dk/nyheder/hvad-erbiomasse-og-hvorfor-loser-det-ikke-vores-klimaproblemer/. Accessed 13/0820182018

20. Dansk Energi, Dansk Fjernvarme (2013) Biomasse til Energi - derfor skal træpiller og flis erstatte kul og gas. Dansk Energi og Dansk Fjernvarme

21. Dansk Skovforening, Skovdyrkerforeningerne, HedeDanmark A/S (2013) Danmarks forsyning af træflis i fremtidens energimarked [Denmark's supply of wood chips in the energy market of the future].

22. Dong Energy (2010) DONG Energy: Biomass for heat and power experience and perspectives. DONG Energy,

23. DONG Energy Thermal Power A/S (2017) Statusrapport for Bæredygtig Biomasse for DONG Energy Thermal Power A/S [Status Report for Sustainable Biomass for DONG Energy Thermal Power A/S] 
24. DRAX (2018) Responsible Sourcing. https://www.drax.com/sustainability/ sourcing/. Accessed 15/08-2018

25. DRAX (2019) ForestScope. http://forestscope.info/. Accessed 27-04-2019

26. EA Energianalyse (2016) Brændeforbrug i Danmark 2015, Undersøgelse af brændeforbruget, og antallet af brændeovne, pejse, masseovne og brændekedler i danske boliger og fritidshuse [Fire wood consumption in Denmark 2015, Investigation of fire wood consumption and the number of wood stoves, fire places, mass furnaces and wood boilers in Danish homes and recreational houses]. EA Energianalyse, Copenhagen

27. EA Energianalyse (2017) Det danske træpillemarked 2016 [The Danish wood pellet market 2017]. EA Energianalyse, Copenhagen

28. EA Energy Analyses, Danish Energy Agency (2018) Biomass Statistics: firewood. Copenhagen Denmark

29. EA Energy Analyses, Danish Energy Agency (2018) Biomass Statistics: wood chips. Copenhagen, Denmark

30. EA Energy Analyses, Danish Energy Agency (2018) Biomass Statistics: wood pellets. Copenhagen, Denmark

31. EA Energy Analyses, Danish Energy Agency (2018) Biomass Statistics: wood waste. Copenhagen, Denmark

32. Ebeltoft Fjernvarmeværk a.m.b.a. (2017) Statusrapport for Bæredygtig Biomasse for Ebeltoft Fjernvarmeværk a.m.b.a. [Status Report for Sustainable Biomass for Ebeltoft District Heating Plant a.m.b.a.].

33. Ebeltoft Fjernvarmeværk a.m.b.a. (2018) Statusrapport for Bæredygtig Biomasse for Ebeltoft Fjernvarmeværk a.m.b.a. [Status Report for Sustainable Biomass for Ebeltoft Fjernvarmeværk a.m.b.a.].

34. Energi- Forsynings- og Klimaministeriet (2018) Lov om ændring af lov om fremme af vedvarende energi og lov om elforsyning vol LOV $\mathrm{nr}$ 1532 af 18/12/2018.

35. Energistyrelsen (2014) Analyse af bioenergi i Danmark [Analysis of bioenergy in Denmark]. Energistyrelsen,

36. Energistyrelsen (2016) Danmarks energifortider - Hovedbegivenheder på energiområdet [Denmark's energy history - major events on the energy field]. Energistyrelsen, København, DK

37. Energistyrelsen (2017) Energiproducenttællingen 2016 [Energy Producer Count 2016]. Copenhagen

38. Energistyrelsen (2018) Energistatistik 2017 [Energy Statistics 2017]. Energistyrelsen, Copenhagen

39. Energistyrelsen (2018) Notat: Oversigt over støtteregler mv. for elproduktion baseret på vedvarende energi og anden miljøvenlig elproduktion [in Danish]. Energistyrelsen, Copenhagen

40. Environmental NGOs (2016) A New EU Sustainable Bioenergy Policy Proposal to regulate bionergy production and use on the EU's renewable energy policy framework 2020-2030.

41. ENVIVA (2019) Track and Trace. http://www.envivabiomass.com/ sustainability/track-and-trace/. Accessed 27-04-2019

42. Euro Heat and Power (2018) District Energy in Denmark. https://www.euroheat. org/knowledge-centre/district-energy-denmark/. Accessed 30-11-2018

43. European Commission (2010) Report from the Commission to the Council and the European Parliament on sustainability requirements for the use of solid and gaseous biomass sources in electricity, heating and cooling SEC(2010) 65 final SEC(2010) 66 final

44. European Commission (2016) Proposal for a DIRECTIVE OF THE EUROPEAN PARLIAMENT AND OF THE COUNCIL on the promotion of the use of energy from renewable sources (recast) vol COM(2016) 767 final. Brussels

45. European Commission (2018) The Energy Union gets simplified, robust and transparent governance: Commission welcomes ambitious agreement. European Comission, Brussels

46. European Parliament and the Council of the European Union (2009) Directive 2009/28/EC of the European Parliament and of the Council of 23 April 2009 on the promotion of the use of energy from renewable sources and amending and subsequently repealing Directives 2001/77/EC and 2003/30/EC. 2009/28/EC.

47. Fargione J, Hill J, Tilman D, Polasky S, Hawthorne P (2008) Land clearing and the biofuel carbon debt science 319:1235-1238 doi: https://doi.org/10.1126/ science. 1152747

48. Fjernvarme Fyn Produktion A/S (2017) Statusrapport for Bæredygtig Biomasse for Fjernvarme Fyn Produktion A/S [Status Report for Sustainable Biomass for Fjernvarme Fyn Produktion A/S

49. Fjernvarme Fyn Produktion A/S (2018) Statusrapport for Bæredygtig Biomasse for Fjernvarme Fyn Produktion A/S [Status Report for Sustainable Biomass for Fjernvarme Fyn Produktion A/S].
50. Fritsche U, Iriarte L (2014) Sustainability Criteria and Indicators for the Bio-Based Economy in Europe: State of Discussion and Way Forward. Energies 7:6825

51. Grenaa Kraftvarmeværk v. Verdo Produktion A/S (2018) Statusrapport for Bæredygtig Biomasse for Grenaa Kraftvarmeværk v. Verdo Produktion A/S [eng. Status Report for Sustainable Biomass for Grenaa Combined Heat and Power Plant at Verdo Produktion a/S].

52. Haderslev Fjernvarme A.m.b.A. (2017) Statusrapport for Bæredygtig Biomasse for Haderslev Fjernvarme AMBA (Status Report for Sustainable Biomass for Haderslev Fjernvarme AMBA).

53. Haderslev Fjernvarme A.m.b.A. (2018) Statusrapport for Bæredygtig Biomasse for Haderslev Fjernvarme A.m.b.A. [Status Report for Sustainable Biomass for Haderslev District Heating A.m.b.A.].

54. Halsnæs Varme A/S (2018) Statusrapport for Bæredygtig Biomasse for Halsnæs Varme A/S [Status Report for Sustainable Biomass for Halsnæs Heat A/S].

55. Hillerød Forsyning (2017) Anvendelse af biomasse til varmeproduktion $i$ Hillerød Forsyning - Statusrapport for dokumentation af bæredygtig biomasse i perioden august - december 2016 [Utilization of biomass for heat production in Hillerød Utility - Status report for documentation of sustainable biomass in the period August - December 2016].

56. Hillerød Forsyning (2018) Anvendelse af biomasse til varmeproduktion i Hillerød Forsyning - Statusrapport for dokumentation af bæredygtig biomasse i 2017 [Utilization of biomass for heat production in Hillerød Forsyning - Status report for documentation of sustainable biomass in 2017].

57. Hjørring Varmeforsyning A.m.b.a. (2017) Statusrapport for Bæredygtig Biomasse for Hjørring Varmeforsyning A.m.b.a. [Status Report for Sustainable Biomass for Hjørring Heat Utility A.m.b.a.].

58. Hjørring Varmeforsyning A.m.b.a. (2018) Statusrapport for Bæredygtig Biomasse for Hjørring Varmeforsyning A.m.b.a. [Status Report for Sustainable Biomass for Hjørring Varmeforsyning A.m.b.a.\}.

59. HOFOR (2017) Statusrapport for Bæredygtig Biomasse for HOFOR A/S [Status Report for Sustainable Biomass for HOFOR A/S].

60. HOFOR (2018) Statusrapport for Bæredygtig Biomasse for HOFOR A/S [Status Report for Sustainable Biomass for HOFOR A/S].

61. HOFOR (2019) Bæredygtig Biomasse [in Danish]. HOFOR. https://www.hofor. $\mathrm{dk} /$ baeredygtige-byer/amagervaerket/baeredygtig-omstilling-paaamagervaerket/baeredygtig-biomasse/. Accessed 14-03 2019

62. HOFOR (2019) BIO4 - anlægsdesign [in Danish]. https://www.hofor.dk/ baeredygtige-byer/amagervaerket/bio4-projektet/bio4-anlaegsdesign/. Accessed 26 Apr 2019

63. Kitzing L, Mitchell C, Morthorst PE (2012) Renewable energy policies in Europe: Converging or diverging? Energy Policy 51:192-201. https://doi.org/ 10.1016/j.enpol.2012.08.064

64. Klima- Energi og bygningsministeriet (2012) Bedre rammer for bioenergien.

65. Klima og Energiministeriet (2010) National Action Plan for Renewable Energy in Denmark. Klima og Energiministeriet, Copenhagen

66. Klimarådet (2018) Biomassens betydning for grøn omstilling Klimaperspektiver og anbefalinger til regulering af fast biomasse til energiformål [The importance of biomass for the green transition - Climate perspectives and recommendations for regulation of solid biomass for energy purposes]. Klimarådet, Copenhagen

67. Kyoto Protocol (1997) United Nations Framework Convention on Climate Change.

68. Lamers P, Mai-Moulin T, Junginger M (2016) Chapter 8 - Challenges and Opportunities for International Trade in Forest Biomass. In: Thiffault $E_{\text {, }}$ Berndes G, Junginger M, Saddler JN, Smith CT (eds) Mobilisation of Forest Bioenergy in the Boreal and Temperate Biomes. Academic Press, pp 127164. https://doi.org/10.1016/B978-0-12-804514-5.00008-1

69. Larsen S, Bentsen NS, Dalgaard T, Jørgensen U, Olesen JE, Felby C (2017) Possibilities for near-term bioenergy production and GHG-mitigation through sustainable intensification of agriculture and forestry in Denmark Environmental Research Letters 12 doi: https://doi.org/10.1088/1748-9326/aa9001

70. Lattimore B, Smith CT, Titus B, Stupak I, Egnell G (2013) Woodfuel harvesting: a review of environmental risks, criteria and indicators, and certification standards for environmental sustainability. Journal of Sustainable Forestry 32:58-88. https://doi.org/10.1080/10549811.2011.651785

71. Lipp J (2007) Lessons for effective renewable electricity policy from Denmark, Germany and the United Kingdom. energy policy 35:5481-5495. https://doi.org/10.1016/j.enpol.2007.05.015

72. Lopatin E, Trishkin M, Gavrilova O (2016) Assessment of Compliance with PEFC Forest Certification Indicators with Remote Sensing. Forests 7:85 
73. Mai-Moulin T, Armstrong S, van Dam J, Junginger M (2019) Toward a harmonization of national sustainability requirements and criteria for solid biomass. Biofuels, Bioproducts and Biorefining 13:405-421. https://doi.org/ 10.1002/bbb.1822

74. Mansoor M, Stupak I, Smith T (2016) Private regulation in the bioenergy sector. In: Le Bouthillier Y, Cowie A, Martin P, McLeod-Kilmurray H (eds) The Law and Policy of Biofuels. Edward Elgar Publishing, pp 406-438

75. Miljø- og Fødevareministeriet (2018) Høringsnotat vedrørende Udkast til Danmarks Nationale Skovprogram. Miljø- og Fødevareministeriet"

76. Miljø- og Fødevareministeriet, Naturstyrelsen; (2018) Certificering Statsskovene [Certification in State Forests]. https://naturstyrelsen.dk annonceringer/udbud/certificering-i-statsskovene/. Accessed 12-09-2018

77. Netherlands Enterprise Agency (2018) Sustainability criteria for solid biomass. Netherlands Enterprise Agency. https://english.rvo.nl/subsidiesprogrammes/sde/sustainability-criteria. Accessed 11-12-2018

78. Ørsted (2018) Statusrapport for Bæredygtig Biomasse for Ørsted Bioenergy and Thermal Power A/S [Status Report for Sustainable Biomass for Ørsted Bioenergy and Thermal Power A/S]

79. Ørsted (2019) Sustainability - to build an entirely green world. Ørsted. https://orsted.com/en/Sustainability. Accessed 14-03 2019

80. Regeringen, Det Konservative Folkeparti, Venstre, Socialistisk Folkeparti (1993) Aftale mellem regeringen, Det Konservative Folkeparti, Venstre og Socialistisk Folkeparti om øget anvendelse af biomasse i energiforsyningen og til industrielle formål.

81. Scarlat N, Dallemand J-F (2011) Recent developments of biofuels/bioenergy sustainability certification: A global overview. Energy Policy 39:1630-1646. https://doi.org/10.1016/j.enpol.2010.12.039

82. Schulze ED, Körner C, Law BE, Haberl H, Luyssaert S (2012) Large-scale bioenergy from additional harvest of forest biomass is neither sustainable nor greenhouse gas neutral. GCB Bioenergy 4:611-616

83. Searchinger TD et al (2018) Europe's renewable energy directive poised to harm global forests. Nature Communications 9:3741. https://doi.org/10. 1038/s41467-018-06175-4

84. Sekretariatet for afgifts- og tilskudsanalysen på energiområdet (2016) Afgiftsog tilskudsanalysen på energiområdet. Delanalyse 1: Udviklingen i afgiftsog tilskudsgrundlag [Charges and subsidies in the energy sector. Subanalysis 1: Development in the basis for charges and subsidies]. Sekretariatet for afgifts- og tilskudsanalysen på energiområdet, København

85. Skanderborg-Hørning Fjernvarme (2018) Statusrapport for Bæredygtig Biomasse for Skanderbrog-Hørning Fjernvarme [Status Report for Sustainable Biomass for Skanderborg-Hørning District Heating].

86. Skanderborg-Hørning-Fjernvarme A.M.B.A. (2017) Statusrapport for Bæredygtig Biomasse Skanderborg-Hørning-Fjernvarme A.M.B.A. [Status Report for Sustainable Biomass for Skanderborg-Hørning-District Heating A.M.B.A.].

87. Socialdemokraterne, Det Radikale Venstre, Socialistisk Folkeparti, Venstre, Dansk Folkeparti, Enhedslisten, Det Konservative Folkeparti (2012) Aftale mellem regeringen (Socialdemokraterne, Det Radikale Venstre, Socialistisk Folkeparti) og Venstre, Dansk Folkeparti, Enhedslisten og Det Konservative Folkeparti om den danske energipolitik 2012-2020 [Agreement between the government (Socialdemokraterne, Det Radikale Venstre, Socialistisk Folkeparti) og Venstre, Dansk Folkeparti, Enhedslisten og Det Konservative Folkeparti about the Danish energy policy 2012-2020).

88. Sønderborg Fjernvarme a.m.b.a (2017) Statusrapport for Bæredygtig Biomasse for Sønderborg Fjernvarme AMBA [Status Report for Sustainable Biomass for Sønderborg District Heating AMBA].

89. Sønderborg Fjernvarme A.m.b.a. (2018) Statusrapport for Bæredygtig Biomasse for Sønderborg Fjernvarme A.m.b.A. [Status Report for Sustainable Biomass for Sønderborg District Heating A.m.b.A.].

90. Stupak I, Olesen AS (2015) Bæredygtighed og certificering af biomasse [Sustainability and certification of biomass]. University of Copenhagen and COWl, Kongens Lyngby

91. Sustainable Biomass Program (2019) About us. https://sbp-cert.org/about-us. Accessed 27-04-2019

92. Tarm Varmeværk A.m.b.a. (2017) Statusrapport for Bæredygtig Biomasse for Tarm Varmeværk A.m.b.a. [Status Report for Sustainable Biomass for Tarm Heating Plant A.m.b.a.]

93. Tarm Varmeværk A.m.b.a. (2018) Statusrapport for Bæredygtig Biomasse for Tarm Varmeværk A.m.b.a. [Status Report for Sustainable Biomass for Tarm Heating Plant A.m.b.a.].

94. The European Parliament and the Council of the European Union (2001) Directive 2001/77/EC of the European Parliament and of the Council of 27
September 2001 on the promotion of electricity produced from renewable energy sources in the internal electricity market.

95. The European Parliament and the Council of the European Union (2010) REGULATION (EU) No 995/2010 OF THE EUROPEAN PARLIAMENT AND OF THE COUNCIL of 20 October 2010 laying down the obligations of operators who place timber and timber products on the market (Text with EEA relevance) vol 995/2010. The European Parliament and the Council of the European Union.

96. The European Parliament and the Council of the European Union (2018) DIRECTIVE (EU) 2018/2001 OF THE EUROPEAN PARLIAMENT AND OF THE COUNCIL of 11 December 2018 on the promotion of the use of energy from renewable sources (recast) (Text with EEA relevance).

97. Trishkin M, Lopatin E, Karjalainen T (2015) Exploratory Assessment of a Company's Due Diligence System against the EU Timber Regulation: A Case Study from Northwestern Russia. Forests 6:1380-1396

98. VEKS (2017) Dokumentation i henhold til Brancheaftalen om sikring af bæredygtigt biomasse fro VEKS [Documentation according to the Industry Agreement for securing sustainable biomass for VEKS]

99. VEKS (2018) Dokumentation i henhold til Brancheaftalen om sikring af bæredygtigt biomasse for VEKS - 2017 [Documentation according to the Industry Agreement about securing sustainable biomass for VEKS - 2017].

100. Venstre et al. (2018) Energiaftale af 29. juni 2018 [Energy agreement of 29 june, 2018]

101. VERDO (2017) Statusrapport for Bæredygtig Biomasse for Randers Kraftvarmeværk v. Verdo Produktion A/S [Status Report for Sustainable Biomass for Randers Combined Heat and Power Plant at Verdo Production A/S].

102. VERDO (2018) Statusrapport for Bæredygtig Biomasse for Randers Kraftvarmeværk v. Verdo Produktion A/S [Status Report for Sustainable Biomass for Randers Combined Heat and Power Plant at Verdo Production A/S].

103. Werner S (2017) International review of district heating and cooling. Energy 137:617-631. https://doi.org/10.1016/j.energy.2017.04.045

\section{Publisher's Note}

Springer Nature remains neutral with regard to jurisdictional claims in published maps and institutional affiliations.

Ready to submit your research? Choose BMC and benefit from:

- fast, convenient online submission

- thorough peer review by experienced researchers in your field

- rapid publication on acceptance

- support for research data, including large and complex data types

- gold Open Access which fosters wider collaboration and increased citations

- maximum visibility for your research: over $100 \mathrm{M}$ website views per year

At $\mathrm{BMC}$, research is always in progress.

Learn more biomedcentral.com/submissions 